\title{
Investigation of Survivin Gene Polymorphism and Serum Survivin Levels in Patients with Brain Tumors
}

\author{
DIDEM KAFADAR ${ }^{1,2}$, ILHAN YAYLIM $^{1}$, ALI METIN KAFADAR ${ }^{3}$, CANAN CACINA $^{1}$, \\ ARZU ERGEN ${ }^{1}$, MEHMET YASAR KAYNAR ${ }^{3}$ and TURGAY ISBIR ${ }^{4}$ \\ ${ }^{1}$ Department of Molecular Medicine, Aziz Sancar Institute of Experimental Medicine, \\ Istanbul University, Istanbul, Turkey; \\ ${ }^{2}$ Department of Family Medicine, Bagcilar Training and Research Hospital, \\ Health Sciences University, Istanbul, Turkey; \\ ${ }^{3}$ Neurosurgery Department, Istanbul University Cerrahpasa Medical Faculty, Istanbul, Turkey; \\ ${ }^{4}$ Department of Medical Biology, Faculty of Medicine, Yeditepe University, Istanbul, Turkey
}

\begin{abstract}
Background/Aim: The single nucleotide polymorphism $-31 C / G$ identified in the survivin gene promoter seems to be associated with over-expression of survivin, an anti-apoptotic protein. In gliomas, increased survivin expression correlated with decreased survival. The aim of the study was to investigate whether survivin gene polymorphism associates with benign and malignant brain tumors and whether it affects survivin serum levels. Patients and Methods: Survivin polymorphism $-31 C>G$ was genotyped in 82 patients with brain tumors and 65 healthy controls by polymerase chain reaction-restriction fragment length polymorphism (PCR-RFLP) and survivin levels were evaluated by enzyme-linked immuno sorbent assay (ELISA) in patients and controls. Results: Serum survivin levels in patients with malignant tumors were higher than patients with benign tumors $(p<0.001)$. Survivin levels in patients with malignant glial tumors and the frequency of the $G G$ genotype were higher than in patients with benign tumors $(p=0.04)$ and controls $(p=0.05)$. The prevelance of the survivin gene promoter polymorphism $-31 C>G$ did not differ between patients and controls. Conclusion: Survivin promoter $-31 C>G$ gene polymorphism seems to be associated with serum survivin levels in brain tumors of different grades and histologies.
\end{abstract}

Molecular research findings have provided novel insights into the mechanisms of pathogenesis of brain tumors but their importance in predicting response to treatment and

Correspondence to: Prof. Dr. Ilhan Yaylım, Istanbul University Aziz Sancar DETAE 34390 P.O. Box 7 Capa/Istanbul, Turkey. Tel/Fax: +90 2126351959, e-mail: ilhanyaylim@gmail.com

Key Words: Apoptosis, brain tumors, genes, polymorphism, survivin. clinical progression is still unclear (1). Apoptosis is important both in embryogenesis and tissue homeostasis (2). Possible associations between expression of apoptotic markers such as bcl-2, bax, fas/fasL, survivin and p53 in brain tumors and disease prognosis have been investigated to identify prognostic markers (1). During fetal development, survivin, a member of the inhibitor of apoptosis gene family (IAP), is expressed to promote cell proliferation by inhibiting apoptosis, but in adult tissues it is scarcely detected (3). Survivin mRNA expression in adult brain is detected at a very low level when compared to survivin mRNA expression in normal fetal brain (4).

Meningiomas arising from meningoepithelial cells are mostly slow-growing benign lesions and patients are diagnosed usually during middle and old ages. There is evidence that deregulation of cell cycle has an important role in meningioma progression. Molecular mechanisms of formation, growth and malignant transformation of meningiomas are being investigated and newly discovered genetic changes have been associated with different tumor grades $(5,6)$.

Studies in recent decades have shown that primary and secondary glioblastomas may be associated with altered genetic and molecular pathways which involve activation and inactivation of several tumor supressor genes and oncogenes, MGMT promoter methylation status as well as gain and loss of heterozygosity such as 10q (7-9). Alterations in signaling pathways of $R T K / R A S / M A P K / P I 3 K A$; the 553 pathway - TP53, p14ARF, MDM2, MDM4; the RB pathway - CDKN2A/CDKN2B, CDK4/CDK6, RB1 and changes in metabolic pathways involving mutations in isocitrate dehydrogenase-1 (IDHI) and IDH2 are commonly reported involved in glioblastoma pathogenesis (10-13).

In primary glioblastomas, epidermal growth factor receptor (EGFR) amplification, PTEN mutations and p16 INK4a deletions and absence of $I D H$ mutations are more common, 
whereas early and frequent TP53 mutations and IDH mutations are present in secondary glioblastomas $(10,12,13)$.

The survivin gene (BIRC5) is located on chromosome $17 q 25$, spanning approximately $14.7 \mathrm{~kb}$ and consists of 4 exons and 3 introns (3).

Survivin protein expression has been identified in most human cancers and high survivin expression has been found to be correlated with disease recurrence and decreased survival in malignancies including colorectal cancer (14), lung cancer (15) and renal cell carcinoma (16).

There is an inbalance between cell proliferation and apoptosis in carcinogenesis. Survivin protein is associated with both regulation of mitosis and inhibition of apoptosis. It has been suggested that by overexpression of survivin, the apoptotic check point is overcome and transformation of cells proceeds $(17,18)$. Survivin promoter single nucleotide $-31 \mathrm{G}>\mathrm{C}$ polymorphism is located on the CDE/CHR repressor binding region in the promoter of the gene $(3,17)$. The function of survivin in cell division and cell death networks has been investigated in order to determine its importance for cancer prognosis (18). It has been shown that changes in cell cycle dependent transcription in cancer cell lines and this polymorphism are associated with changes in both mRNA and protein levels (19). Survivin is frequently expressed in meningiomas and gliomas and it has been suggested that it is associated with tumor progression and poor prognosis (20). Several studies have examined the association of survivin gene promoter $-31 \quad \mathrm{C}>\mathrm{G}$ polymorphism with different types of cancer (21-24).

In this study, the association between survivin gene $31 \mathrm{C}>\mathrm{G}$ polymorphism with brain tumors and the relationship between serum survivin levels and survivin polymorphism were investigated.

\section{Patients and Methods}

Patient selection and clinical investigation. A total of 82 patients with brain tumors were included in the current study. All cases were treated at the Neurosurgery Clinic of the Medical Faculty of the University within a period of 6 months. The diagnoses of the patients were determined by radiological and operative findings and confirmed by pathological examination. The blood samples were collected from the patients before any treatment (chemotherapy or radiotherapy). Malignancy status and histological origin were considered in grouping as arising from glial and meningothelial (nonglial) cells according to WHO classification of tumours of the central nervous system in 2007. Grade I tumors are benign and grades II, III and IV are considered as malignant (25).

The control group consisted of 65 healthy individuals who did not have any benign or malignant tumors and any family history of tumors.

The present study was approved by the Ethical Committee of Medical Faculty of the University. The informed consent was taken from all patients and healthy controls. The protocol followed was consistent with the Declaration of Helsinki.
DNA isolation. Blood specimens were collected in tubes containing EDTA, and DNA samples were extracted from whole blood as previously described (26).

Survivin gene $-31 \mathrm{C}>\mathrm{G}$ polymorphism genotypes were determined using a polymerase chain reaction-restriction fragment length polymorphism (PCR-RFLP) analysis. A 341-bp PCR amplification product of survivin $-31 \mathrm{C}>\mathrm{G}$ polymorphism was detected by using the forward 5'-GTT CTT TGAAAGCAGTCGAG-3'and reverse 5'GCCAGTTCTTGAATGTAGAG -3' primers: The reaction mix contained, 50-100 ng genomic DNA, 1xpolymerase chain reaction (PCR) buffer, $0.2 \mathrm{mM}$ of each dNTP, $3 \mathrm{mM} \mathrm{MgCl} 2,0.2 \mathrm{mM}$ of each primer and $0.5 \mathrm{U}$ of Taq polymerase (MBI Fermentas, Lithuania) in a $25 \mathrm{ml}$ reaction volume. The PCR reactions were started with an initial denaturation of the DNA at $94^{\circ} \mathrm{C}$ for $5 \mathrm{~min}$, followed by 35 cycles of denaturation $94^{\circ} \mathrm{C}$ for $30 \mathrm{sec}$, annealing at $57^{\circ} \mathrm{C}$ for $90 \mathrm{sec}$ and extension at $72^{\circ} \mathrm{C}$ for $90 \mathrm{sec}$. The final elongation step was at $72^{\circ} \mathrm{C}$ for $5 \mathrm{~min}$. The PCR products were digested with EcoO109I restriction enzyme (MBI Fermentas, Lithuania) at $37^{\circ} \mathrm{C}$ for $16 \mathrm{~h}$ followed by electrophoresis in $2 \%$ agarose gel containing ethidium bromide. The CC genotype lacks a EcoO109I site and shows only one band of $341 \mathrm{bp}$. The genotype GG generates two fragments of 236 and $105 \mathrm{bp}$. The heterozygote GC genotype displays three fragments of 341,236 and 105 bp (24).

Serum survivin levels. The survivin serum levels were determined in blood samples by Enzyme-Linked Immuno Sorbent Assay (ELISA) using Survivin EIA kit (human Total Survivin TiterZyme ${ }^{\circledR}$ EIA kit, Assay designs).

Statistical analysis. All statistical analyses were carried out using the SPSS version 7.5 statistical package for Windows. Student $t$ test or Mann-Whitney $U$-test, chi-square test, and Kruskal-Wallis tests were used to assess both the prevalence of the genotype of the survivin promoter region and allele frequencies and the levels of survivin protein between groups. Chi-square test or Fisher's exact test was also used to calculate Odds Ratio (OR) with $95 \%$ confidence intervals $(95 \% \mathrm{CI})$ to determine whether survivin genotypes were associated with the disease. The threshold for significance was $p<0.05$.

\section{Results}

The patients' group involved $44.4 \%$ women and $55.6 \%$ men while the control group consisted of $45.5 \%$ women and $54.5 \%$ men. The mean age of the 82 patients was $61.57 \pm 14.34$ years and the mean age of the 65 controls was $57.18 \pm 11.52$. Those aged 60 years and less were $90.6 \%$ in the control group and $80 \%$ among patients $(p=0.164)$. There were no significant differences between genders $(p=0.890)$ and mean ages of patients and controls $(p=0.809)$. None of the healthy individuals was smoking while $29.3 \%$ of the patients were smokers $(p=0.001)$.

Only primary intracranial tumors were included in the study. The majority of the patients had gliomas $(n=43$; $52.4 \%)$ or meningiomas $(n=31 ; 37.8 \%)$. The remaining patients had cranial nerve tumors $(\mathrm{n}=3 ; 3.7 \%)$, cellar region tumors $(\mathrm{n}=3 ; 3.7 \%)$, lymphoma and hematopoetic neoplasms $(\mathrm{n}=2 ; 2.4 \%)$. 
Kafadar et al: Survivin Gene Polymorphism and Serum Survivin Levels in Brain Tumors

Table I. Survivin promoter $-31 C>G$ genotype allele distribution in primary brain tumors classified according to the malignancy status and histology.

\begin{tabular}{lccccc}
\hline $\begin{array}{l}\text { Genotypes } \\
-31 \mathrm{C}>\mathrm{G}\end{array}$ & $\begin{array}{c}\text { Malignant non-glial } \\
\text { tumor patients } \\
\mathrm{n}(\%)\end{array}$ & $\begin{array}{c}\text { Malignant glial } \\
\text { Tumor patients } \\
\mathrm{n}(\%)\end{array}$ & $\begin{array}{c}\text { Benign non-glial } \\
\text { tumor patients } \\
\mathrm{n}(\%)\end{array}$ & $\begin{array}{c}\text { Benign glial } \\
\text { tumor patients } \\
\mathrm{n}(\%)\end{array}$ \\
\hline $\mathrm{CC}$ & $4(36.4)$ & $4(10.5)$ & $4(14.3)$ & $0(0)$ & $\begin{array}{c}\text { Controls } \\
\mathrm{n}(\%)\end{array}$ \\
$\mathrm{GC}$ & $5(45.5)$ & $21(55.3)$ & $14(50)$ & $3(60)$ & $2(12.3)$ \\
GG & $2(18.2)$ & $13(34.2)$ & $22(35.7)$ & $3(40)$ & $31(47.7)$ \\
C allel & $13(59)^{\mathrm{a}}$ & $29(38.2)$ & $34(60.7)$ & $7(70)$ & $42(32.3)$ \\
G allel & $9(41)$ & $47(61.8)$ & $88(67.7)$ \\
\hline
\end{tabular}

${ }^{\mathrm{a}} p=0.02$; comparison of malignant non-glial tumor patients and control group.

Table II. Survivin promoter $-31 C>G$ allele distribution according to characteristics of patients with meningeal tumors.

\begin{tabular}{|c|c|c|c|c|c|c|c|c|c|c|}
\hline \multirow[b]{2}{*}{ Patient characteristics } & \multicolumn{10}{|c|}{ Genotypes } \\
\hline & $\begin{array}{c}\mathrm{CC}+\mathrm{CG} \\
\mathrm{N}(\%)\end{array}$ & $\begin{array}{c}\text { GG } \\
\mathrm{N}(\%)\end{array}$ & $\mathrm{N}$ & $p$-Value & $\begin{array}{c}\text { OR } \\
95 \% \mathrm{CI}\end{array}$ & $\begin{array}{c}\mathrm{GG}+\mathrm{GC} \\
\mathrm{N}(\%)\end{array}$ & $\begin{array}{c}\mathrm{CC} \\
\mathrm{N}(\%)\end{array}$ & $\mathrm{N}$ & $p$-Value & $\begin{array}{c}\text { OR } \\
95 \% \mathrm{CI}\end{array}$ \\
\hline \multicolumn{11}{|l|}{ Gender } \\
\hline Men & $12(85.7)$ & $2(14.3)$ & 14 & 0.068 & $1.619(0.985-2.66)$ & $11(78.6)$ & $3(21.4)$ & 14 & 0.698 & $1.113(0.738-1.679)$ \\
\hline Women & $9(52.9)$ & $8(47.1)$ & 17 & & & $12(70.6)$ & $5(29.4)$ & 17 & & \\
\hline \multicolumn{11}{|l|}{ Smoking status } \\
\hline Smoker & $7(77.8)$ & $2(22.2)$ & 9 & 0.677 & $1.222(0.763-1.957)$ & $6(66.7)$ & $3(33.3)$ & 9 & 0.66 & $0.863(0.516-1.443)$ \\
\hline Nonsmoker & $14(63.6)$ & $8(36.4)$ & 22 & & & $17(77.3)$ & $5(22.7)$ & 22 & & \\
\hline \multicolumn{11}{|l|}{ Age 1} \\
\hline$<45$ years & $7(77.8)$ & $2(22.2)$ & 9 & 0.675 & $1.256(0.774-2.039)$ & $4(44.4)$ & $5(55.6)$ & 9 & $0.03 *$ & $0.519(0.245-1.099)$ \\
\hline$\geq 45$ years & $13(61.9)$ & $8(38.1)$ & 21 & & & $18(85.7)$ & $3(14.3)$ & 21 & & \\
\hline \multicolumn{11}{|l|}{ Age 2} \\
\hline$<60$ years & $15(62.5)$ & $9(37.5)$ & 24 & 0.633 & $0.750(0.467-1.204)$ & $18(75)$ & $6(25)$ & 24 & 0.645 & $1.125(0.611-2.073)$ \\
\hline$\geq 60$ years & $5(83.3)$ & $1(16.7)$ & 6 & & & $4(66.7)$ & $2(33.3)$ & 6 & & \\
\hline \multicolumn{11}{|l|}{ Tumor grade } \\
\hline III and IV & $3(100)$ & 0 & 3 & 0.533 & $1.556(1.180-2.050)$ & $1(33.3)$ & $2(66.7)$ & 3 & 0.156 & $0.424(0.085-2.127)$ \\
\hline I and II & $18(64.3)$ & $10(35.7)$ & 28 & & & $22(78.6)$ & $6(21.4)$ & 28 & & \\
\hline \multicolumn{11}{|l|}{ Malignancy status } \\
\hline Malign & $8(88.9)$ & $1(11.1)$ & 9 & 0.205 & $1.504(0.991-2.284)$ & $5(55.6)$ & $4(44.4)$ & 9 & 0.185 & $0.679(0.366-1.258)$ \\
\hline Non-malign & $13(59.1)$ & $9(40.9)$ & 22 & & & $18(81.8)$ & $4(18.2)$ & 22 & & \\
\hline \multicolumn{11}{|l|}{ Frontal location } \\
\hline No & $20(66.7)$ & $10(33.3)$ & 30 & 1.00 & $0.667(0.518-0.859)$ & $22(73.3)$ & $8(26.7)$ & 30 & 1.00 & $0.733(0.591-0.910)$ \\
\hline Yes & $1(100)$ & $0(0)$ & 1 & & & $0(0)$ & $1(100)$ & 1 & & \\
\hline
\end{tabular}

Patients with malignant tumors and benign tumors were $63.2 \%$ and $36.8 \%$ of patients, respectively. Yamada et al. have grouped tumors as glial malign, glial nonmalign, nonglial malignant and nonglial nonmalignant (27). So, we also grouped the tumors according to their malignancy level considering histology and behavior as malign-glial (51.3\%), malign-nonglial (12\%); benign non-glial (30.8\%) and benign glial $(6 \%)$ according to literature classification (25).

The GG, GC and CC genotype frequencies of survivin gene polymorphism $-31 \mathrm{C}>\mathrm{G}$ for controls and patients are presented in Table I. There were no statistically significant differences in survivin $-31 \mathrm{C}>\mathrm{G}$ genotypes and allele frequencies between the controls and the patients.
In meningeal tumor patients, there was no significant relationship between survivin gene promoter $-31 \mathrm{C}>\mathrm{G}$ polymorphism and patient characteristics including gender, smoking, tumor grade, and malignancy status. However G allele frequency was significantly lower in patients diagnosed at ages younger than 45 years while the CC genotype was higher in this group (Table II).

In glial tumor patients, there was no significant relationship between survivin gene promoter $-31 \mathrm{C}>\mathrm{G}$ polymorphism and patient characteristics including gender, age, tumor grade, and malignancy status. However, smokers carried the $\mathrm{CC}$ genotype at a significantly lower frequency than non-smokers (Table III). 
Table III. Survivin promoter $-31 C>G$ allele and tumor characteristics in patients with glial tumors.

\begin{tabular}{|c|c|c|c|c|c|c|c|c|c|c|}
\hline \multirow[b]{2}{*}{ Patient characteristics } & \multicolumn{10}{|c|}{ Genotypes } \\
\hline & $\begin{array}{c}\mathrm{CC}+\mathrm{CG} \\
\mathrm{N}(\%)\end{array}$ & $\begin{array}{c}\text { GG } \\
\mathrm{N}(\%)\end{array}$ & $\mathrm{N}$ & $p$-Value & $\begin{array}{c}\text { OR } \\
95 \% \mathrm{CI}\end{array}$ & $\begin{array}{c}\mathrm{GG}+\mathrm{GC} \\
\mathrm{N}(\%)\end{array}$ & $\begin{array}{c}\mathrm{CC} \\
\mathrm{N}(\%)\end{array}$ & $\mathrm{N}$ & $p$-Value & $\begin{array}{c}\mathrm{OR} \\
95 \% \mathrm{CI}\end{array}$ \\
\hline \multicolumn{11}{|l|}{ Gender } \\
\hline Men & $19(73.1)$ & 7 (26.9) & 26 & 0.176 & $1.380(0.833-2.288)$ & $23(88.5)$ & $3(11.5)$ & 26 & 1.00 & $0.940(0.783-1.128)$ \\
\hline Women & $9(52.9)$ & $8(47.1)$ & 17 & & & $16(94.1)$ & $1(5.9)$ & 17 & & \\
\hline \multicolumn{11}{|l|}{ Smoking status } \\
\hline Smoker & $13(76.5)$ & $4(23.5)$ & 17 & 0.266 & $1.275(0.842-1.929)$ & $13(76.5)$ & $4(23.5)$ & 17 & $0.021 *$ & $0.765(0.587-0.995)$ \\
\hline Nonsmoker & $15(60)$ & $10(40)$ & 25 & & & $25(100)$ & 0 & 25 & & \\
\hline \multicolumn{11}{|l|}{ Age 1} \\
\hline$<45$ years & $12(54.5)$ & $10(45.5)$ & 22 & 0.081 & $0.682(0.439-1.059)$ & $20(90.9)$ & $2(9.1)$ & 22 & 1.00 & $1.010(0.829-1.230)$ \\
\hline$\geq 45$ years & $16(80)$ & $4(20)$ & 20 & & & $18(90)$ & $2(10)$ & 20 & & \\
\hline \multicolumn{11}{|l|}{ Age 2} \\
\hline$<60$ years & $22(61.1)$ & $14(38.9)$ & 36 & 0.083 & $0.611(0.471-0.793)$ & $33(91.7)$ & $3(8.3)$ & 36 & 0.474 & $1.100(0.759-1.594)$ \\
\hline$\geq 60$ years & $6(100)$ & $0(0)$ & 6 & & & $1(16.7)$ & $5(83.3)$ & 6 & & \\
\hline \multicolumn{11}{|l|}{ Tumor grade } \\
\hline III and IV & $22(68.8)$ & $10(31.3)$ & 32 & 0.473 & $1.260(0.700-2.269)$ & $28(87.5)$ & $4(12.5)$ & 32 & 0.558 & $0.875(0.768-0.997)$ \\
\hline I and II & $6(54.5)$ & $4(45.5)$ & 11 & & & $11(100)$ & $0(0)$ & 11 & & \\
\hline \multicolumn{11}{|l|}{ Malignancy status } \\
\hline Malign & $25(65.8)$ & $13(34.2)$ & 38 & 1.00 & $1.096(0.517-2.325)$ & $34(89.5)$ & $4(10.5)$ & 38 & 1.00 & $0.895(0.802-0.998)$ \\
\hline Non-malignant & $2(40)$ & $3(60)$ & 5 & & & $5(100)$ & $0(0)$ & 5 & & \\
\hline \multicolumn{11}{|l|}{ Frontal location } \\
\hline No & $22(78.6)$ & $6(21.4)$ & 28 & 0.011 & $1.964(1.026-3.760)$ & $25(89.3)$ & $3(10.7)$ & 28 & 1.00 & $0.957(0.794-1.153)$ \\
\hline Yes & $6(40)$ & $9(60)$ & 15 & & & $14(93.3)$ & $1(6.7)$ & 15 & & \\
\hline
\end{tabular}

Serum survivin levels and genotypes. Survivin serum levels in patients with primary brain tumors according to their histology are presented in Table IV. A significant difference in serum survivin levels $(\mathrm{pg} / \mathrm{ml})$ among patient groups $(p<0.001)$ was found.

In patients with aggressive glioblastoma multiforme (GBM) and survivin (promoter $-31 \mathrm{C}>\mathrm{G}$ ) CC, GC and GG genotypes, the serum survivin levels were $21.7,20.9 \pm 4.7,47.7 \pm 8.7$, respectively. Patients with GG genotype had significantly higher serum survivin levels than controls carrying the same genotype (23.6 \pm 6.3$),(p=0.032)$, (Table V).

\section{Discussion}

Survivin is thought to contribute to the formation and development of tumors and increased levels of survivin may be a negative prognostic factor for tumor growth (17). It is suggested that when survivin-microtubule interactions are disrupted in $\mathrm{G}_{2} / \mathrm{M}$ phase, overexpression of survivin may favor apoptosis rather than acting as an inhibitor (28). This may explain the different results of survivin expression in various cancers.

Yamada et al. (27) grouped tumors as malign/benign and glioma/nonglioma and examined the relationship between survivin expression and histologic malignity in brain tumor samples. They reported that malignant tumors expressed survivin mRNA at significantly higher levels than benign tumors and gliomas also expressed higher levels of survivin mRNA than nongliomas (27).

Survivin promoter $-31 C>G$ gene polymorphism genotypes. In the present study, survivin promoter $-31 \mathrm{C}>\mathrm{G}$ gene polymorphism genotypes and allele frequencies between patients and controls were not different. In patients with tumors originating from meninges the frequency of the $\mathrm{C}$ allele was significantly higher than the control group. $\mathrm{C}$ allele carriers were significantly higher in malignant nonglial patients, than in the control group.

In addition, $\mathrm{C}$ allele frequency was found significantly higher in various cancers (22). Wang et al. found that $\mathrm{C} / \mathrm{G}$ and $\mathrm{C} / \mathrm{C}$ genotype carriers have increased risk of urothelial carcinoma compared to individuals with $\mathrm{G} / \mathrm{G}$ genotype (21). It has been reported that in patients with lung cancer, $G$ allele carriers have less risk of developing cancer than $\mathrm{CC}$ carriers and that $\mathrm{G}$ allele has significantly less promoter activity than $\mathrm{C}$ allele (29). Gazouli et al. reported that in patients with colorectal cancer, $-31 \mathrm{C}$ allele and CC genotype frequency are significantly higher compared to healthy individuals and, furthermore, survivin mRNA levels in CC carriers were more than those in $G$ allele carriers (22). In 
Table IV. Survivin serum levels in patients with primary brain tumors classified according to the malignancy status and histology (pg/ml).

\begin{tabular}{lccccc}
\hline & $\begin{array}{c}\text { Malignant } \\
\text { non-glial } \\
\text { tumors }\end{array}$ & $\begin{array}{c}\text { Malignant } \\
\text { glial } \\
\text { tumors }\end{array}$ & $\begin{array}{c}\text { Benign } \\
\text { non-glial } \\
\text { tumors }\end{array}$ & $\begin{array}{c}\text { Benign } \\
\text { glial } \\
\text { tumors }\end{array}$ & $\begin{array}{c}\text { Control } \\
\text { group }\end{array}$ \\
\hline Survivin Serum Levels $(\mathrm{pg} / \mathrm{ml})$ & $17.14 \pm 7.18^{\mathrm{a}}$ & $36.6 \pm 3.70^{\mathrm{b}, \mathrm{c}, \mathrm{d}}$ & $13.11 \pm 3.95^{\mathrm{e}}$ & $13.50 \pm 7.38$ & $25.7 \pm 3.36$ \\
\hline
\end{tabular}

${ }^{\mathrm{a}} p=0.021$; malignant glial tumor patients compared to malignant non-glial tumor patients; ${ }^{\mathrm{b}} p<0.001$; malignant glial tumor patients compared to benign non-glial tumor patients; ${ }^{\mathrm{c}} p=0.039$; malignant glial tumor patients compared to benign glial tumor patients; ${ }^{\mathrm{d}} p=0.024$; malignant glial tumor patients compared to control group; ${ }^{\mathrm{e}} p=0.021$; benign non-glial tumor patients compared to control group.

Table V. Serum survivin levels ( $\mathrm{pg} / \mathrm{ml})$ and Survivin Promoter -31C>G genotypes according to malignancy and histology.

\begin{tabular}{|c|c|c|c|c|c|c|c|c|c|c|c|c|c|c|c|}
\hline \multirow[b]{2}{*}{$-31 \mathrm{C}>\mathrm{G}$ Genotype } & \multicolumn{3}{|c|}{$\begin{array}{c}\text { Malignant } \\
\text { non-glial } \\
\text { tumors }\end{array}$} & \multicolumn{3}{|c|}{$\begin{array}{l}\text { Malignant } \\
\text { glial } \\
\text { tumors }\end{array}$} & \multicolumn{3}{|c|}{$\begin{array}{l}\text { Benign } \\
\text { non-glial } \\
\text { tumors }\end{array}$} & \multicolumn{3}{|c|}{$\begin{array}{l}\text { Benign } \\
\text { glial } \\
\text { tumors }\end{array}$} & \multicolumn{3}{|c|}{ Controls } \\
\hline & $\mathrm{CC}$ & GC & GG & $\mathrm{CC}$ & $\mathrm{GC}$ & GG & $\mathrm{CC}$ & $\mathrm{GC}$ & GG & $\mathrm{CC}$ & $\mathrm{GC}$ & GG & $\mathrm{CC}$ & $\mathrm{GC}$ & GG \\
\hline $\begin{array}{c}\text { Serum survivin } \\
\text { levels }(\mathrm{pg} / \mathrm{ml})\end{array}$ & $\begin{array}{c}18.4 \pm \\
11.4\end{array}$ & $\begin{array}{c}35.4 \pm \\
34.4\end{array}$ & $\begin{array}{c}13.4 \pm \\
12.4\end{array}$ & 21.7 & $\begin{array}{c}28.5 \pm \\
6.2\end{array}$ & $\begin{array}{l}41.6 \pm \\
8.1^{\mathrm{a}, \mathrm{b}}\end{array}$ & $\begin{array}{c}4.1 \pm \\
3.1\end{array}$ & $\begin{array}{c}20.8 \pm \\
8.4\end{array}$ & $\begin{array}{c}12.9 \pm \\
6.5^{\mathrm{a}}\end{array}$ & - & $\begin{array}{c}10.7 \pm \\
9.7\end{array}$ & 5.8 & $\begin{array}{c}26.4 \pm \\
13.2\end{array}$ & $\begin{array}{c}30.6 \pm \\
5.6\end{array}$ & $\begin{array}{c}23.6 \pm \\
6.3^{\mathrm{b}}\end{array}$ \\
\hline
\end{tabular}

${ }^{\mathrm{a}} p=0.041$; malignant glial tumor patients compared to benign non-glial tumor patients; ${ }^{\mathrm{b}} p=0.059$; malignant glial tumor patients compared to control group.

another study, association of gastric cancer risk and $\mathrm{G}$ allele carrier status was not detected, but GG and GC was found to be associated with distal gastric cancer and welldifferentiated tumors (23). Cheng et al. found that $\mathrm{C}$ allele and $\mathrm{CC}$ genotype frequency in survivin gene promoter $31 \mathrm{C}>\mathrm{G}$ polymorphism were significantly higher in patients with stomach cancer than healthy controls but there was no association between genotypes and survivin mRNA (30). In breast cancer patients, the prevalence of genotype $\mathrm{GC}+\mathrm{CC}$ was significantly higher compared with the control group (31). However, Borbely et al., reported that survivin gene promoter $-31 \mathrm{C}>\mathrm{G}$ polymorphisms were not associated with increased risk in cervical cancer development (24).

According to our results, in meningeal tumor patients, $G$ allele frequency was significantly lower in patients diagnosed at ages younger than 45 years, while the $\mathrm{CC}$ genotype was higher in this group. The $\mathrm{C}$ allele may be associated with a young onset of meningeal origin tumors, whereas the $G$ allele may be associated with young onset of malignant glial tumors. In GBM patients under 45, the GG genotype was significantly higher than in patients over 45 .

It has been reported that the mean age of patients with secondary glioblastomas was 45 years (10). De novo and secondary gliomas affect patients at different ages through different pathways (7). There may be different molecular mechanisms in GBM development. Advanced patient age is a negative prognostic factor. Primary glioblastomas tend to develop in older patients (mean, 50-55 years), whereas patients with secondary glioblastoma are typically diagnosed at around 40 years of age $(10,32)$.

Serum survivin levels and survivin genotypes. Survivin expression increases with the degree of malignity of cancers. In colorectal cancer, survivin expression increased in adenoma, low grade dysplasia (2.3\%), high grade dysplasia (52.4\%) and carcinoma (63.3\%) (14). In pancreatic ductal adenocarcinomas, the highest expression is found in ductal carcinoma while there is not any expression in normal pancreatic canals (33). Survivin expression has been found to increase as malignity increases, by $21.2 \%$ in benign tumors, $47.8 \%$ in borderline tumors and $51.2 \%$ in carcinomas of ovaries (34).

In human malignities, increased survivin expression may be associated with tumor aggressiveness and poor prognosis. It has been suggested that altered binding to the CDE/CHR repressor motive of the survivin gene promoter $-31 \mathrm{C}>\mathrm{G}$ polymorphism changes cell cycle transcription and thus both survivin mRNA and survivin protein level are effected (19).

In our study, serum survivin levels of patients with tumors originating from glial cells were found to be significantly higher than survivin levels of patients with tumors originating from non-glial cells and the latter had significantly lower levels than the controls. Thus, in our 
patients with malignant nonglial tumors, serum survivin levels were significantly lower than the patients with malignant glial tumors.

Survivin levels have been examined in body fluids such as urine of patients with bladder cancer for diagnostic and prognostic reasons $(21,35)$.

Survivin levels in serum and urine of node-positive breast cancer patients patients were significantly higher than serum levels in node negative patients (36). Following chemotherapy of patients with locally advanced gastric cancer, serum survivin levels were significantly higher than controls and this may be used for the prediction of response to chemotherapy (37).

In another study, patients with nonsmall cell lung cancer and controls had similar survivin serum levels, but patients who responded to chemotherapy had decreasing levels of survivin (38).

High cytoplasmic survivin levels were reported to be associated with glioblastoma while high p53 expression and high nuclear survivin expression were associated with anaplastic astrocytoma (39). Furthermore, it was shown that the presence of high p53 levels or cytoplasmic or nuclear survivin in diffuse astrocytic tumors were associated with better prognosis following radiotherapy (39). It was also reported that in different grades of gliomas survivin may have different effects on prognosis (40).

In our study, the serum survivin levels in patients with malignant glial tumors with GG genotype were significantly higher than in patients with benign nonglial tumors and also controls having the same genotype. Patients with advanced neuroepithelial tumors carrying the GG genotype had higher survivin levels. Chakravarti et al., reported that patients with higher grade tumors (III.-IV.) had higher levels of survivin in sera than those patients with more benign tumors (I.-II. grade) and increase in survivin expression significantly correlated with decreased survival times in gliomas (40).

Uematsu et al. concluded that high nuclear survivin expression may be a negative prognostic factor in gliomas, while Preusser et al. reported that nuclear expression of survivin in GBM patients did not have an effect on prognosis $(41,42)$.

In a recent meta-analysis of 16 studies, it was concluded that prognosis in patients with gliomas was associated with high expression of survivin (43). Whether survivin is expressed in the nucleus or cytoplasm has different impact on prognosis according to recent studies (41-44). The differences in the results of the studies regarding expression and quantity may be due to the lack of a standardized procedure involving precise cut-off values for expression of survivin (45).

This study was performed before WHO 2016 guidelines, which recommends molecular markers to be involved in the identification of tumors of the central nervous system, were established (46). Our findings are similar to studies involving survivin mRNA and survivin protein level.
Strengths and limitations of the study. Number of patients may seem as a limitation at first, but it should be considered that we have chosen our group of patients according to very strict criteria, which is one of the strengths of this study and patient numbers are similar to studies involving brain tumors. All patients had pathologically-proven primary brain tumors after brain surgery and patients with metastatic tumors in brain were excluded. The patients should be followed in order to obtain precise results about prognosis and genotype relationship and the study must be verified in larger patient groups.

\section{Conclusion}

Survivin gene promoter $-31 \mathrm{C}>\mathrm{G}$ polymorphism seems to be associated with serum survivin levels in brain tumors with different grades and histologies. Malignant glial tumor patients with GG genotype, had higher survivin levels than benign non-glial tumor patients and controls having the same genotype. The findings of our study may have a clinical value in evaluating the prognosis and genetic risks of brain tumors besides providing a view into the underlying mechanisms of brain tumors.

\section{Conflicts of Interest}

The Authors declare no conflicts of interest.

\section{Acknowledgements}

The present work was supported by the Research Fund of Istanbul University; Project No: 867.

\section{References}

1 Konstantinidou AE, Korkolopoulou P and Patsouris E: Apoptotic markers for primary brain tumor prognosis. J Neurooncol 72 : 151-156, 2005.

2 Goldsmith KC and Hogarty MD: Targeting programmed cell death pathways with experimental therapeutics: oppurtunities in high-risk neuroblastoma. Cancer Lett 228: 133-141, 2005.

3 Ambrosini G, Adida C and Altieri DC: A novel apoptosis gene, survivin, expressed in cancer and lymphoma. Nat Med 3: 917921, 1997.

4 Andersen MH, Svane IM, Becker JC and Straten PT: The universal character of the tumor-associated antigen survivin. Clin Cancer Res 13: 5991-5994, 2007.

5 Simon M, Boström JP and Hartmann C: Molecular genetics of meningiomas: from basic research to potential clinical applications. Neurosurgery 60(5): 797-798, 2007

6 Commins D, Roscoe DA and Burnett EM: Review of meningioma histopathology. Neurosurg. Focus 23(4): E3, 1-9, 2007.

7 Bayani J, Pandita A and Square JA: Molecular cytogenetic analysis in the study of brain tumors: findings and applications Neurosurg Focus 19(5): E1, 1-36, 2005. 
8 Xie D, Zeng YX, Wang HJ, Wen JM, Tao Y, Sham JST and Guan XY: Expression of cytoplasmic and nuclear Survivin in primary and secondary human glioblastoma. Brit J Cancer 94: 108-114, 2006.

9 Olar A and Aldape KD: Using the molecular classification of glioblastoma to inform personalized treatment. J Pathol 232(2): 165-177, 2014.

10 Ohgaki $\mathrm{H}$ and Kleihues P: Genetic pathways to primary and secondary glioblastoma. Am J Pathol 170(5): 1445-1453, 2007.

11 Cancer Genome Atlas Research Network: Comprehensive genomic characterization defines human glioblastoma genes and core pathways. Nature 455: 1061-1068, 2008.

12 Parsons DW, Jones S, Zhang X, Lin JC-H, Leary RJ, Angenendt P, Mankoo P, Carter H, Siu I-M, Gallia GL, Olivi A, McLendon R, Rasheed BA, Keir S, Nikolskaya T, Nikolsky Y, Busam DA, Tekleab H, Diaz LA Jr., Hartigan J, Smith DR, Strausberg RL, Marie SKN, Shinjo SMO, Yan H, Riggins GJ, Bigner DD, Karchin R, Papadopoulos N, Parmigiani G, Vogelstein B, Velculescu VE and Kinzler KW: An integrated genomic analysis of human glioblastoma multiforme. Science 321: 1807-1812, 2008.

13 Polivka J Jr., Polivka J, Holubec L, Kubikova T, Priban V, Hes $\mathrm{O}$, Pivovarcikova K and Treskova I: Advances in experimental targeted therapy and 1mmunotherapy for patients with glioblastoma multiforme. Anticancer Res 37(1): 21-33, 2017.

14 Kawasaki H, Toyoda M, Shinohara H, Okuda J, Watanabe I, Yamamoto T, Tanaka K, Tenjo T and Tanigawa N: Expression of survivin correlates with apoptosis, proliferation, and angiogenesis during human colorectal tumorigenesis. Cancer 91: 2026-2032, 2001.

15 Monzó M, Rosell R, Felip E, Astudillo J, Sánchez JJ, Maestre J, Martín C, Font A, Barnadas A and Abad A: A novel antiapoptosis gene: Re-expression of survivin messenger RNA as a prognosis marker in non-small-cell lung cancers. J Clin Oncol 17: 2100-2104,1999.

16 Pu Z, Wang Q, Xie H, Wang G and Hao H: Clinicalpathological and prognostic significance of survivin expression in renal cell carcinoma: a meta-analysis. Oncotarget 8(12): 19825-19833, 2017.

17 Altieri DC: Validating survivin as a cancer therapeutic target. Nat Rev Cancer 3: 46-54, 2003.

18 Altieri DC: Survivin, cancer networks and pathway-directed drug discovery. Nat Rev Cancer 8(1): 61-70, 2008.

$19 \mathrm{Xu}$ Y, Fang F, Ludewig G, Jones G and Jones D: A mutation found in the promoter region of the human survivin gene is correlated to overexpression of survivin in cancer cells. DNA Cell Biol 23: 527-537, 2004.

20 Söling A, Plugge EM, Schmitz M, Weigle B, Jacob R, Illert J, Holzhausen HJ and Rainov NG: Autoantibodies to the inhibitor of apoptosis protein survivin in patients with brain tumors. Int $\mathbf{J}$ Oncol 30(1): 123-128, 2007.

21 Wang YH, Chiou HY, Lin CT, Hsieh HY, Wu CC, Hsu CD and Shen $\mathrm{CH}$ : Association between survivin gene promoter $-31 \mathrm{C} / \mathrm{G}$ polymorphism and urothelial carcinoma risk in Taiwanese population. Urology 73(3): 670-674, 2009.

22 Gazouli M, Tzanakis N, Rallis G, Theodoropoulos G, Papaconstantinou I, Kostakis A, Anagnou NP and Nikiteas N: Survivin $-31 \mathrm{G} / \mathrm{C}$ promoter polymorphism and sporadic colorectal cancer. Int J Colorectal Dis 24(2): 145-150, 2009.
23 Yang L, Zhu H, Zhou B, Gu H, Yan H, Tang N, Dong H, Sun Q, Cong R, Chen $\mathrm{G}$ and Wang B: The association between the survivin $\mathrm{C}-31 \mathrm{G}$ polymorphism and gastric cancer risk in a Chinese population. Dig Dis Sci 54(5): 1021-1028, 2009.

24 Borbély AA1, Murvai M, Szarka K, Kónya J, Gergely L, Hernádi Z and Veress G: Survivin promoter polymorphism and cervical carcinogenesis. J Clin Pathol 60(3): 303-306, 2007.

25 Kleihues P, Louis DN, Wiestler OD, Burger PC and Scheithauer BW: WHO grading of tumours of the central nervous system. In: WHO Classification of Tumours of the Central Nervous System. 4th ed. Louis DN, Ohgaki H, Wiestler OD, Cavenee WK (eds.) Lyon: International Agency for Research on Cancer (IARC), pp. 10-11, 2007.

26 Miller SA, Dykes DD and Polesky HS: A simple salting out procedure for extracting DNA from human nucleated cells. Nucleic Acids Res 16(3): 1215, 1988.

27 Yamada Y, Kuroiwa T, Nakagawa T, Kajimoto Y, Dohi T, Azuma $\mathrm{H}$, Tsuji M, Kami K and Miyatake S: Transcriptional expression of survivin and its splice variants in brain tumors in humans. $\mathrm{J}$ Neurosurg 99(4): 738-745, 2003.

28 Li F, Ambrosini G, Chu EY, Plescia J, Tognin S, Marchisio PC and Altieri DC: Control of apoptosis and mitotic spindle checkpoint by survivin. Nature 396: 580-584, 1998.

29 Jang JS, Kim KM, Kang KH, Choi JE, Lee WK, Kim CH, Kang YM, Kam S, Kim IS, Jun JE, Jung TH and Park JY: Polymorphisms in the survivin gene and the risk of lung cancer. Lung Cancer 60(1): 31-39, 2008.

30 Cheng ZJ, Hu LH and Huang SJ: Correlation of $-31 \mathrm{G} / \mathrm{C}$ polymorphisms of survivin promoter to tumorigenesis of gastric carcinoma. Ai Zheng 27(3): 258-263, 2008.

31 Rasool I, Afroze D, Wani KA, Yousuf A, Bhat IA, Rah B, Nazir $\mathrm{SU}$, Hussain S and Dubey S: Role of the functional polymorphism of survivin gene $(-31 \mathrm{G} / \mathrm{C})$ and risk of breast cancer in a North Indian population. Clin Breast Cancer 18(4): e671-e676, 2018.

32 Dropcho EJ and Soong SJ: The prognostic impact of prior lowgrade histology in patients with anaplastic gliomas: A casecontrol study. Neurology 47(3): 684-690, 1996.

33 Bhanot U, Heydrich R, Moller P and Hasel C: Survivin expression in pancreatic intraepithelial neoplasia (PanIN): steady increase along the developmental stages of pancreatic ductal adenocarcinoma. Am J Surg Pathol 30: 754-759, 2006.

34 Sui L, Dong Y, Ohno M, Watanabe Y, Sugimoto K and Tokuda M: Survivin expression and its correlation with cell proliferation and prognosis in epithelial ovarian tumors. Int J Oncol 21: 315$320,2002$.

$35 \mathrm{Li} \mathrm{X}$, Wang Y, Xu J and Zhang Q: Sandwich ELISA for detecting urinary Survivin in bladder cancer. Chin J Cancer Res 25(4): 375-381, 2013.

36 Güney N, Soydine HO, Derin D, Camlica H, Duranyildiz D, Yasasever V and Topuz E: Serum and urine survivin levels in breast cancer. Med Oncol 23(3): 335-340, 2006.

37 Bozkaya Y, Özdemir NY, Sezer S, Köstek O, Demirci NS, Yazıcı $\mathrm{O}$, Erdem GU, Eren $\mathrm{T}$ and Zengin $\mathrm{N}$ : Is serum survivin expression a predictive biomarker in locally advanced gastric cancer patients treated with neoadjuvant chemotherapy? Cancer Biomark 22(1): 143-149, 2018.

38 Derin D, Soydinç HO, Guney N, Tas F, Camlica H, Duranyildiz D, Yasasever V and Topuz E: Serum levels of apoptoz biomarkers, survivin and TNF-alpha in nonsmall cell lung cancer. Lung Cancer 59(2): 240-245, 2008. 
39 Faccion RS, Bernardo PS, de Lopes GPF, Bastos LS, Teixeira CL, de Oliveira JA, Fernandes PV, Dubois LG, Chimelli L and Maia RC: p53 expression and subcellular survivin localization improve the diagnosis and prognosis of patients with diffuse astrocytic tumors. Cell Oncol 41(2): 141-157, 2018.

40 Chakravarti A, Noll E, Black PM, Finkelstein DF, Finkelstein DM, Dyson NJ and Loeffler JS: Quantitatively determined survivin expression levels are of prognostic value in human gliomas. J Clin Oncol 20: 1063-1068, 2002.

41 Uematsu M, Ohsawa I, Aokage T, Nishimaki K, Matsumoto K, Takahashi H, Asoh S, Teramoto A and Ohta S: Prognostic significance of the immunohistochemical index of survivin in gliom: a comparative study with the MIB-1 index. J Neurooncol 72(3): 231-238, 2005.

42 Preusser M, Gelpi E, Matej R, Marosi C, Dieckmann K, Rössler $\mathrm{K}$, Budka $\mathrm{H}$ and Hainfellner JA: No prognostic impact of survivin expression in glioblastoma. Acta Neuropathol 109: 534$538,2005$.
43 Zhang S, Zhang C, Song Y, Zhang J and Xu J: Prognostic role of survivin in patients with glioma.Medicine (Baltimore) 97(17): e0571, 2018.

44 Mellai M, Caldera V, Patrucco A, Annovazzi L and Schiffer D: Survivin expression in glioblastomas correlates with proliferation, but not with apoptosis. Anticancer Res 28(1A): 109-118, 2008.

45 Varughese RK and Torp SH: Survivin and gliomas: A literature review. Oncol Lett 12(3): 1679-1686, 2016.

46 Louis DN, Perry A, Reifenberger G, von Deimling A, FigarellaBranger D, Cavenee WK, Ohgaki H, Wiestler OD, Kleihues P and Ellison DW: The 2016 World Health Organization Classification of Tumors of the Central Nervous System: a summary. Acta Neuropathol 131(6): 803-820, 2016.

Received August 11, 2018

Revised September 10, 2018

Accepted September 17, 2018 